\title{
A Model for Adopting and Using E-Filing
}

\author{
Mogaramedi Frans Mashabela \\ Unisa Graduate School of Business Leadership (SBL), \\ Corner Janadel and Alexandra Avenues, Midrand, 1685 \\ Gauteng Province, South Africa
}

\begin{abstract}
The adoption and usage of e-filing applications is a phenomenon most governments, including South Africa are still grappling with, and therefore, an ongoing information systems business leadership research is a key issue. The research problem is that despite the e-Government application being implemented and maintained at a high cost, there is little uptake and optimal use. The revenue application has greater benefits such as tax calculation accuracy, tax submission done timeously during any time of the day, improving tax efficiency by reducing administration cost. Since the value and the investment is huge, the burning question is then why the accepting and usage ofe-filing by taxpayers not as it should? Information from previous studies arequite on this phenomenon, in the South Africancontext and this then left a knowledge gaps, which this paper bridges.This paperfocuses on explaining and explore adopting and using e-filing as reasons why some of taxpayers accept and use the revenue application while others are not using it are still unknown. Argument is that despite South Africa implemented a cutting-edgesystemsince 2006, taxpayers still queueat its branches for manualsubmissions.
\end{abstract}

Keywords:- E-Government, e-filing, Tax knowledge, Tax Compliance, Technology acceptance and usage models i.e. Unified Theory of Acceptance and Use of Technology,Total Task Fit and Tax Compliance Models.

\section{INTRODUCTION}

This paperexplores adopting and usingthe e-filing for submission of tax returns. Everyone who is earning an income is required by law in South Africa, to file tax returns annually. Taxpayers may either submit tax returns via online through the e-filing or they can physically goto a tax branch office to manually file tax returns.

According to Ishola (2016), tax is a compulsory levy collected by the tax authority from individual taxpayers and organisations in line with the tax laws of a country. Ibid, 2016, pointed that a fair system taxation is recommended and it need to be convenientand efficient.Taxes are payableon any type of earnings (Ibid, 2016). Biggest fear of users of information system globally is commonly the concern of sharing personal and confidential information when using any technology via online platforms. Laudon and Laudon (2013), mentioned that there is lots of vulnerabilities to many kinds of threats when huge personal data is kept in an electronic form than when in physical manual paper form. Chances of unauthorised access to data

\author{
Professor Ray M Kekwaletswe \\ Unisa Graduate School of Business Leadership (SBL), \\ Corner Janadel and Alexandra Avenues, Midrand, 1685 \\ Gauteng Province, South Africa
}

which is stored electronically is evitable because data misuse can take place at any point where the system can be accessed. It is very critical that the tax authority's website for e-filing must be highly secured as it is used by many taxpayers whose personal data might be at stake. Advice by Crews (2013), is that users of information system must avoid the usage of free public Wi-Fi as it lacks security from data manipulations by third parties when accessing the system. For example, the introduction of the Covid-19 pandemic globally, have increased the need for the usage of online platforms for services like the e-filing, offering of educational class sessions for schools, including tertiary institutions, etc. The implementation of e-filing in South Africa had moved it upwards on the world rankings on tax processing from position 32 to position 11 (Berger, 2011). It takes 200hours for a company in South Africa to process a tax return while the global average is 268 hours (Berger, 2011).

United States of America was the first to use a system of filing returns through electronically in 1986 (Lai and Choong, 2010). Users are motivated to submittheir returnselectronically on time and accuratelywhen they are treated fairly (Kirchler, Niemirowski and Wearing, 2006).Taxpayers cooperate willingly when they are fairly treated, rules justifiable, decisions clarified, correct information provided when questions are asked and problems resolved(Kirchler, Niemirowski \& Wearing, 2006).A reliably integrated system in economically disadvantage countries is still to be implemented even thoughe-filing is accepted globally by citizens(Azmi and Kamarulzaman, 2010). Globally, e-services do not satisfyusers of those systems because of scepticism, absence of digital skills, no system trust, complicated outcomes due to inadequate guidelines, etc. (Lee, Kim andAhn, 2011). Taxpayers without computer skillsmight have challenges in submittingtheir returnselectronically(Lee, Kim \& Ahn, 2011). Easiness of usingtechnology is crucialto the one who use such applications, thus user-friendly systems (Wirtz and Piehler 2016). Mustapha (2015), mentioned thatsuccessfulimplementation of e-tax depends on easy to useas a vital determinant while Gilbert, Balestrini \& Littleboy(2004),identified taxpayers not preferringe-filing than the traditional filing of returns if the application is enjoyable and ease to use.User acceptance to use an information system for the functionalitysupported by the designshowtheir willingness (Dillon and Morris, 1996). Tax system that is not simple to use is a barrier for convenience, clarity and collection economies, system updates must be done continuously to be simplified (Marcus, 2007). 


\section{e-Government}

Gupta, Dasgupta \& Gupta (2008) defines eGovernment as the application of information system. According to United Nations [UN] (2005), e-Government is explained as a usage and application of information system for service delivery to citizens. Leitner, 2003; Beynon \& Davies (2005), stated that electronic services are the tools provided by a government to make its democracy, transparency, and accountability better including its performance. Carter \& Belanger (2005), mentioned that eGovernment promotessimplicity ofaccess for essential government services by its citizens.

Pardo et al. (2016), stated the vision of e-Governance being to establish improved public services offered forby governmentstoattain its objectives efficiently and effectively. According to United Nations (2016b), electronic government provideprovidesadequate services to peopleas an important tool encourage citizens to participate in raising issues pertaining to services provided.. Government administrations globally invest large sum of money annually in e-Government projects (World Bank 2016). Acceptingand using the e-Government by citizens (G2C) remains low globally across the world (Shalhoub 2006; World Bank 2016).

Main reasons for lower adoption rate of eGovernment have were observed to be security, trust, risks involved and individual privacy (Shalhoub 2006; Zafiropoulos, Karavalisis and Vrana 2012). South African government implemented e-Government revenue applications also known as e-filing in 2006 via its tax authority being the South African Revenue Services (SARS), to enable electronic tax form submission for all taxpayers to utilise when doing tax returns (SANews, 2013).

\section{$>$ Stages for e-Government}

Models for e-Government have similar components and stages but only differs in terminology ofeach stage(Rorissa, Demissie and Pardo, 2011). Four stages ofonline services as identified by Rorissa et al., (2011), initial stage which runs parallel with the manual process to offeran option for those who are not able to access information electronically. Stage which follow is the relationship between government and citizens through a phone or electronic platforms for providing services. Interaction onthis stage involves electronic participation and electronic democracy asstrategies for improving engagement of citizens by politicians in government (Missingham, 2011). Electronicpayments made to the government includinginformation received viaonlinesignifyingthe stage of transaction completion. Last transformational stage involves inputs being processed into electronic governance resultsorgovernment services and interactions are done only electronically. At this stage, the government is fully restructured in its back and front office management systems (Weerakkody, Janssen and Dwivedi, 2011; Cloete, 2005). Virtual government is experienced at this stage in sectors where services are provided electronically. E-Government service in South
Africa is at the earlystage regarding e-filing for tax return submissionhence manual tax returns arestill accepted at its branch offices.

\section{- Adopting and usinginformation system}

Fu, Farn\& Chao (2006) describes information system adoption by users being psychological state of mind regardinguser's voluntary intention to use ICT.Perceived easy to use is the willingnessa personhave for believe the use ofcertainapplication will not require human effort to action the task to be done (Davis, 1991). Effortlessness in using a technology to perform a task is a user's subjective perception.Factors for perceived ease of use are: easiness, readable, simple language, comparable information and effortless when moving to the first page (Davis, 1991). Perceived easiness of using information system affect person's perception for learning and usage of technology (Venkatesh, 2000).

\section{$>$ Electronic filing as an e-Government tool for services}

Electronic filing is an application suitable for submission of returns to tax authority via the internet platforms (Barodiva and Bhargava, 2015). Electronic filing of tax return is a tool used by government deliver services to the community via an online platform ( Fu, Farn, and Chao, 2006). Revenue application improves efficiency tax payments and quick refunds processing (Santhanamery and Ramayah, 2015). Accurate calculation of tax is the important benefit of the e-filing because proof of submission is acknowledged immediately by the tax authority(Ibid., 2015). Tax administrative costs and workload decreases due to e-filing usage (Azmi \& Kamarulzaman, 2010; Santhanamery \& Ramayah, 2015). Electronic filing user must have basic computing skills and knowledge of information system for internet browsing.

E-filing use internet platforms where physical paperreturn is not required (Wasao, 2014). E-tax automates tax processes for submitting tax return with a aim of advancing efficiency(Fu et.al.,2006; Dowe, 2008; Fenwick and Browstone, 2002).

\section{$>$ Benefits of e-filing}

Auto-calculation of tax in computing minimises human errors and improves efficiency for processing (Santhanamery and Ramayah (2015).Authorities do not manually capture the tax returns which minimises mistakesduring tax return processing (Santhanamery and Ramayah (2015).Tax return processing costs, safekeeping and handling are minimised (Azmi and Kamarulzaman, 2010). Taxpayers submit their returns at any time, which is convenient, and they system give notificationimmediately confirming transaction done.(Kumar and Anees, 2014).

\section{$>$ Concerns about the e-filing}

Ideally,fair tax system is necessary and should besimplified, enforceable and support economic prosperity for the community it serves (Slemrod and Bakija, 1996). It is inevitable for taxpayers' personal informationto be subjected to security risksas e-filing uses internet platform (Hoffman, Novak and Peralta, 1999). For a taxpayer to file 
tax return successfully, they need to have basic computing skills as well as the knowledge of information technology to be able to browse the internet (Wirtz and Piehler, 2016).

Taxpayers are afraid of using the revenue application due to threats to their private information, forgery and identity theft (De Castro, Cordero, De Chavez, Gabia, Mortel, Yortas, Manongsong \& Pateña, 2015).Taxpayers adopting and usinge-filingare affected by the security threat fear for their personal information and that prevent them from using it (Lu, Hsu and Hsu, 2005). Perceived lack of security lowers the confidence of taxpayers from adopting and using the revenue application (Moorthy, Samsuri, Hussin, Othman \& Chelliah, 2014; Santhanamery \& Ramayah, 2015). Factors influencingcitizens when usingefiling are trust and transaction security (Rehman, Esichaikul and Kamal,2012). Taxpayers' attitudes areinfluenced by their compliance behaviours as it represents their opportunityforpositive or negative action (Ajzen, 1993). Taxpayers' perceived risks influence their intension to use the electronic filing (De Castro, Cordero, De Chavez, Gabia and Mortel, 2015).Information system developers must thoroughly address system design, good online service and privacy assurance to encourage usersto continue using e-services(Chen, Jubildo, Capistrano \& Yen, 2015).

\section{$>$ E-filing challenges}

Taxpayers incur tax compliance cost like internet usage or the use of a tax consultant who submits returns on his/her behalf even though tax return submission is free ( $\mathrm{Lu}$, Hsu and Hsu, 2005). Citizens need to have basic computing and internet skillsto file returns via electronic filing (Ibid, 2010). As electronic operate on internet platforms, users incur data cost for accessing the revenue application via the internet and if they don't have data the only option will be to file their tax returns manually (Gilbert et al., 2004). When tax season approaches deadlinetaxpayers may experience system slow response due to network traffic as many people access the e-filing at the same time (Azmi and Kamarulzaman, 2010). Acceptance and usage of the online tax is influenced by computer literacy leveland internet infrastructure accessibility (Auyat, 2013). The adoption and usage of an e-tax is influence by taxpayer's confidence with online filingand lackof computer literacy that affect them psychologically (Muhangi, 2012). Taxpayersmight be afraid of using the e-filing on because of lacking computer experience that increases anxiety and stress when using technology (Muhangi, 2012).Taxpayers might have a perception that the system is unreliable if it cannot properly carrylarge information during busy period and that will decrease their intensions of adopting and using it (Nakiwala, 2010).

One of the challenges with regard to revenue application is that user needs to remember password every time when accessing the system (Azmi and Kamarulzaman, 2010). Introduction of e-Governance is a challenge for many governments globally as difficulties might occurs in the initial stage and during system upgrade of the e-
Government sites (Kroukamp, 2005). Security of personal information collected and stored by government might be compromised if its security is breached on their websites (Ibid., 2005). Lack of facilities and internet access lower the level of access to the electronic services the poor communities (OECD, 2003). Illiterate taxpayers are likely not to use technologyservices due to lack of computer skills and general education standard(Kroukamp, 2005). Taxpayers who are physically challenged should find it simpler navigate through e-Government websites, sogovernments must ensure accessibility of their e-services to all citizens (Ibid., 2005). Government as the service provider must embark on awareness campaign to educate people about the advantages e-Governance to improve citizens' confidence and persuade them to use the system (Ibid., 2005).

\section{$>$ Tax knowledge and tax compliance}

Taxpayers' aware about their tax obligation and other tax-related information needed when filing returns to tax authority is known as tax compliance (Hasseldine, Holland \& Rijt, 2009). Awareness of tax obligations for registering and filing tax return depend formal education taxpayer received(Hasseldine, Holland and Rijt, 2009). Complying with tax requirements relates to alevel that a taxpayer fulfil or fails to fulfil his/her tax obligations as prescribed by law(Marziana, Norkhazimah \&Mohmad, 2010). Efficient tax administration system encourages voluntary tax compliance behaviour by using penalties for noncompliance as well as other methods (Marziana, Norkhazimah and Mohmad, 2010).Previous studies put more emphases on taxpayers' perception that tax system fairness is a significant factor influencing tax compliance levels (Marziana, Norkhazimah and Mohmad, 2010). Tax awareness and knowledge influence complying level (Marziana, Norkhazimah and Mohmad, 2010).

Psychologicallybased theories and deterrence-based theory are tax compliance theories (Riahi-Belkaoui, 2014). Theory for deterrence recognised taxpayers as moral utility maximisers being influenced by profit maximization and detection probability when submitting tax returns (RiahiBelkaoui, 2014). Taxpayers evaluate compliance options of whether to not comply with tax obligations together with chances of being detected, and thenchoose the option that maximize favourable tax returns results and manage the risk (Riahi-Belkaoui, 2014). Psychologically basedtheory focuses on taxpayers as being influenced by psychological factors when complying with tax rules, this theory is concerned more about taxpayers' morals and ethical standards (Riahi-Belkaoui, 2014). According to this theory, taxpayer comply with their tax obligations even when chances of being caught areslim, emphasis is on tax education to change individual attitudes towards the tax systems (Ibid., 2014).

\section{$>$ The history of tax compliance}

Compliance with tax requirements has been hostile for long years ago due to tax beingregarded as unfair by taxpayers (Director, Taxworld Organization, April 7, 1999). Tax revolt led Boadecia queen of East Anglia was 
ISSN No:-2456-2165

experienced in 60A.D during the Roman empire, it occurred because of corrupt tax in Great Britain (Director, Taxworld Organization, 1999). The nobles of Aquitaine rebelled against tax policies of Edwardbeing the main factor for reviving a 100 years' war (1337-1453) between Great Britain and France 1369.Solution for tax hostility problem is establishfactors influencingbehaviour of taxpayersand influence same factors for compliance with the tax obligations. Tax in South Africa was levied on all African men who never worked in mines on a 3month employmentaccording to tax levy implemented in 1894 as per Glen Grey Act as being enforce by the imperialist Cecil John Rhodes (van der Berg \& Bhorat, 1999). African rural population paid hut taxes to increase benefits for receiving payments from the mines while labour tax was differentiated via poll (van der Berg and Bhorat, 1999). Income Tax Act 28 of 1914 was firstly adopted in South Africa (van der Berg and Bhorat, 1999). Compliance with tax can be advanced by makingthe administration of tax to be effective and efficientand this topic is of great interest to tax compliance researchers (Silvani, 1992). Tax compliance can be improved by having clear demarcations ofthe administration of tax for effectiveness and efficiency together with administrative control measurements at various levels (Silvani,1992). The Administrative effectiveness play an important role in countries that have high level of tax evasion even though the list of determinants of voluntary complianceis endless (Silvani, 1992).

Effective tax administration needs to address shortfalls listed below at all levels for improving tax compliance as well as restrictionof shifting non-compliance to other areas (Silvani, 1992):

- Gap on unregisteredand registered taxpayers.

- Amount of registered taxpayers compared taxpayers submitting tax returns.

- Potential tax gap compared to tax received as tax return submissions.

- Actual tax paid by taxpayers as compared to what authorities assessed.

Government together with tax authority's image, employees' credibility, company culture and structure and human resource are the critical factors to be consider for achieving good tax compliance prior studies undertaken in Basic key qualities required for a tax administration in the economically disadvantaged countries including South Africa are simplicity and clarity.

\begin{tabular}{|l|l|}
\hline \multicolumn{1}{|c|}{ Source } & \multicolumn{1}{|c|}{ Definition } \\
\hline $\begin{array}{l}\text { Gupta, Dasgupta and Gupta, } \\
2008\end{array}$ & $\begin{array}{l}\text { Electronic government is a known } \\
\text { technology used for providing services. }\end{array}$ \\
\hline United Nations, 2005 & $\begin{array}{l}\text { E-Government is the application of } \\
\text { information system to provide services to } \\
\text { the citizens. }\end{array}$ \\
\hline $\begin{array}{l}\text { Leitner, 2003; Beynon and } \\
\text { Davies 2005 }\end{array}$ & $\begin{array}{l}\text { E-Government services are tools for } \\
\text { improving democracy, transparency, and } \\
\text { accountability. }\end{array}$ \\
\hline Carter and Belanger, 2005 & $\begin{array}{l}\text { Electronic services promotes acces and } \\
\text { simplify the provision of essential services } \\
\text { to people. }\end{array}$ \\
\hline Fu, Farn, and Chao, 2006 & $\begin{array}{l}\text { Technology adoption refers to a person's } \\
\text { psychological state for voluntarily deciding } \\
\text { to use information system. }\end{array}$ \\
\hline Barodiva and Bhargava, 2015 & $\begin{array}{l}\text { Electronic filing is an application for filing } \\
\text { returns va the internet. }\end{array}$ \\
\hline Wasao, 2014 & $\begin{array}{l}\text { Electronic filing is a process f submitting } \\
\text { returns electronically with no need to } \\
\text { submit physical tax return form. }\end{array}$ \\
\hline Farn and Chao, 2006 & $\begin{array}{l}\text { Electronic filing is a tool service delivery } \\
\text { via an online platform. }\end{array}$ \\
\hline
\end{tabular}

Table 1:- Authors' describing e-Government, technology adoption and e-filing

\section{SURVEY OF SCHOLARSHIP}

Theoretical models which were developed in the previous studies forexploring and explain the determinants whichinfluence technology adoption and usage are Theory of Reasoned ActionTechnology Acceptance Model,Theory of Planned Behaviour, Task Technology Fit Model, IS Success Modeland Unified Theory of Acceptance and Use of Technology. These theoriesare not a solution for adopting and using e-filing specifically in South African context.Existing literature have no known model developed which outline factors to consider when adopting and using e-filing including reasons why some taxpayers adopt and use it while other do not adopt and use this e-service. This studydevelops a model which can be practically usedas a solution to the challenges of adopting and using thee-filing in the conditions of South Africa. E-filing is an eGovernment application administered by the South African tax authority which individuals and organisations earning an income need to use when submitting their tax returns. This study focuses on individual taxpayers and gives insights into what really drives themadopt and usage the revenue application as well as factors inhibiting its adoption and usage. This studycontributes theoretically, methodologically, practically and contextually by doing exploration through UTAUT, TTF and Tax Compliance previous theories as lenses forexploring and explainingfactors influencing the adoption and usage for efiling.Aquestionnaire was used to collect data for analysis whereopinions and views of satisfactorily sample size of taxpayers using e-filing as well as those who are not using it were captured. Developed model in this study explores the level to which each factor significantly predict and explainthe adoption and usage of e-filing in the context of South Africa. The tax authority may practically use the developed model to ensure that most taxpayers optimally use the e-filing. 
Table 2 below depicts authors explaining factors which predict technology adoption and usage

Table 2 below depictselements which were assessed in different settings and found being significant factors which influence technology adoption. This study tested these elements to assesstheir relevancy to the conditions of South Africa.

\begin{tabular}{|c|c|c|c|}
\hline $\begin{array}{l}\text { Factors } \\
\text { predicting } \\
\text { technology } \\
\text { acceptance and } \\
\text { usage }\end{array}$ & Title/Description & $\begin{array}{l}\text { From which } \\
\text { Model }\end{array}$ & Author/s \\
\hline $\begin{array}{l}\text { Perceived ease of } \\
\text { use }\end{array}$ & $\begin{array}{l}\text { Perceived usefulness, perceived } \\
\text { ease of use and user } \\
\text { acceptance of information } \\
\text { technology. MIS Quarterly, } \\
\text { 13(3), pp. 319-340. }\end{array}$ & PEOU & Davis, F.D. (1989). \\
\hline $\begin{array}{l}\text { Perceived } \\
\text { usefulness }\end{array}$ & $\begin{array}{l}\text { Perceived usefulness, perceived } \\
\text { ease of use and user } \\
\text { acceptance of information } \\
\text { technology. MIS Quarterly, } \\
\text { 13(3), pp. 319-340. }\end{array}$ & PU & Davis, F.D. (1989). \\
\hline $\begin{array}{l}\text { Performance } \\
\text { Expectancy }\end{array}$ & $\begin{array}{l}\text { User Acceptance of Information } \\
\text { Technology: Toward a Unified } \\
\text { View. MIS Quarterly, 27, 425- } \\
478 .\end{array}$ & UTAUT & $\begin{array}{l}\text { Venkatesh, V., } \\
\text { Morris, M. G and } \\
\text { Davis, G. B (2003). }\end{array}$ \\
\hline $\begin{array}{l}\text { Fffort } \\
\text { Expectancy }\end{array}$ & $\begin{array}{l}\text { User Acceptance of Information } \\
\text { Technology: Toward a Unified } \\
\text { View. MIS Quarterly, 27, 425- } \\
478\end{array}$ & UTAUT & $\begin{array}{l}\text { Venkatesh, V., } \\
\text { Morris, M. G and } \\
\text { Davis, G. B (2003). }\end{array}$ \\
\hline Social Influence & $\begin{array}{l}\text { Information technology } \\
\text { acceptance by individual } \\
\text { professionals: a model } \\
\text { comparison approach. Decision } \\
\text { Sciences, } 32 \text {. }\end{array}$ & $\begin{array}{l}\text { A Model } \\
\text { Comparison } \\
\text { Approach }\end{array}$ & $\begin{array}{l}\text { Chau, Y. K and Hu, } \\
\text { J. H (2001). }\end{array}$ \\
\hline $\begin{array}{l}\text { Performance } \\
\text { Impact }\end{array}$ & $\begin{array}{l}\text { Task-technology fit and } \\
\text { individual performance MIS } \\
\text { Quarterly; Jun 1995; 19, 2; } \\
\text { ABI/INFORM Global pg. 213- } \\
\text { 236. }\end{array}$ & TTF & $\begin{array}{l}\text { Goodhue, D.L and } \\
\text { Thompson, R. L } \\
\text { (1995) }\end{array}$ \\
\hline Tax Behaviour & $\begin{array}{l}\text { Detection Probability and } \\
\text { Taxpayer Compliance: A } \\
\text { Review of the Literature. J. Acc. } \\
\text { Lit. 11: 1-46. }\end{array}$ & $\begin{array}{l}\text { Tax } \\
\text { Compliance } \\
\text { Model }\end{array}$ & $\begin{array}{l}\text { Fischer CM, } \\
\text { Wartick M, Mark M } \\
\text { (1992). }\end{array}$ \\
\hline \multirow{3}{*}{$\begin{array}{l}\text { Behavioural } \\
\text { Intention }\end{array}$} & $\begin{array}{l}\text { The theory of planned } \\
\text { behaviour. Organisational } \\
\text { behaviour and human decision } \\
\text { processes, } 50(1) \text {, pp. 179-211. }\end{array}$ & TPB & Ajzen, I. (1991). \\
\hline & $\begin{array}{l}\text { Belief, Attitude, Intention and } \\
\text { Behaviour: AN Introduction to } \\
\text { theory and Research. Reading, } \\
\text { MA: Addison-Wesley. }\end{array}$ & & \\
\hline & & TRA & $\begin{array}{l}\text { Fishbein, M and } \\
\text { Ajzen, I (1975). }\end{array}$ \\
\hline $\begin{array}{l}\text { Information } \\
\text { quality }\end{array}$ & $\begin{array}{l}\text { The DeLone and McLean model } \\
\text { of information systems success: } \\
\text { A ten-year update. Journal of } \\
\text { Management Information } \\
\text { Systems, 19(4), 9-30. }\end{array}$ & $\begin{array}{l}\text { IS Success } \\
\text { Model }\end{array}$ & $\begin{array}{l}\text { DeLone, W. H., \& } \\
\text { McLean, E. R. } \\
\text { (2003). }\end{array}$ \\
\hline Education & $\begin{array}{l}\text { "User acceptance of } \\
\text { information technology: toward } \\
\text { a unified view", MIS Quarterly, } \\
\text { Vol. } 27 \text { No. 3, pp. } 425-478 .\end{array}$ & UTAUT & $\begin{array}{l}\text { Venkatesh, V., } \\
\text { Morris, M., Davis, } \\
\text { G. and Davis, F. } \\
\text { (2003), }\end{array}$ \\
\hline
\end{tabular}

Table 2:- Authors on factors predicting technology adoption and usage

Table 3 below depicts authors explaining factors which are technology enablers and disablers for adoption and usage.

Table 3 below depicts constructs which have been discovered to significantly enables and disables technology adoption and usage after being tested in various settings globally. The determinants list for thatinhibit or enables the adoption and usage of technology is endless, so frequently assessedelements were chosen.
ISSN No:-2456-2165

\begin{tabular}{|c|c|c|c|}
\hline $\begin{array}{l}\text { Technology } \\
\text { Enablers and } \\
\text { Disablers }\end{array}$ & Description & From which Model & Author \\
\hline $\begin{array}{l}\text { Facilitating } \\
\text { Conditions }\end{array}$ & $\begin{array}{l}\text { "User acceptance of information } \\
\text { technology: toward a unified } \\
\text { view", MIS Quarterly, Vol. } 27 \text { No. } \\
\text { 3, pp. 425-478. }\end{array}$ & UTAUT & $\begin{array}{l}\text { Venkatesh, V., } \\
\text { Morris, M., Davis, G } \\
\text { and Davis, F. (2003), }\end{array}$ \\
\hline Compatibility & $\begin{array}{l}\text { Acceptance of electronic tax filing: } \\
\text { a study of taxpayer intentions. } \\
\text { Information \& Management, } 43 \text {, } \\
\text { pp. 109-126. }\end{array}$ & $\begin{array}{l}\text { A Study of Taxpayer } \\
\text { Intensions }\end{array}$ & $\begin{array}{l}\text { Fu, J.R., Farn, C.K. } \\
\text { and Chao W.P. } \\
\text { (2006). }\end{array}$ \\
\hline & $\begin{array}{l}\text { The role of security and trust in the } \\
\text { adoption of online tax filing. } \\
\text { Transforming Government: People, } \\
\text { Process, Policy, 5(4), pp. 303-318. }\end{array}$ & $\begin{array}{l}\text { Transforming } \\
\text { Government, People, } \\
\text { Processes and Policy }\end{array}$ & $\begin{array}{l}\text { Carter, L., Schaupp, } \\
\text { L.C., Hobbs, J. and } \\
\text { Campbell, R. (2011a). }\end{array}$ \\
\hline Trust & $\begin{array}{l}\text { The U.S. e-file initiative: an } \\
\text { investigation of the antecedents to } \\
\text { adoption from the individual } \\
\text { taxpayers' perspective. E - Service } \\
\text { Journal, 7(3), pp. } 219 .\end{array}$ & $\begin{array}{l}\text { An investigation of } \\
\text { the antecedents to } \\
\text { adoption from the } \\
\text { individual taxpayers' } \\
\text { perspective. }\end{array}$ & $\begin{array}{l}\text { Carter, L., Schaupp, } \\
\text { L.C. and McBride, } \\
\text { M.E. (2011b). }\end{array}$ \\
\hline $\begin{array}{l}\text { Computer Self- } \\
\text { efficacy }\end{array}$ & $\begin{array}{l}\text { The adoption of electronic tax } \\
\text { filing systems: an empirical study. } \\
\text { Government Information Quarterly, } \\
\text { 20(1), pp. 333-352. }\end{array}$ & An Empirical Study & Wang, Y.S. (2002). \\
\hline \multirow[b]{2}{*}{$\begin{array}{l}\text { Tax General } \\
\text { Knowledge }\end{array}$} & $\begin{array}{l}\text { The Association of Chartered } \\
\text { Certified Accountants, ACCA, } \\
\text { London. www.accaglobal.com. }\end{array}$ & $\begin{array}{l}\text { The Management of } \\
\text { Tax Knowledge. }\end{array}$ & $\begin{array}{l}\text { Hasseldine, J., } \\
\text { Holland, K. and Rijt, } \\
\text { P.V. (2009) }\end{array}$ \\
\hline & $\begin{array}{l}\text { Problems and solutions. } \\
\text { ACCAMADIA, Journal of Faculty } \\
\text { of Accountancy, Faculty of } \\
\text { Accountancy, UiTM Shah Alam } \\
\text { 11(2): 6-35. }\end{array}$ & $\begin{array}{l}\text { Taxilliteracy in } \\
\text { Malaysia }\end{array}$ & Barjoyai, B (1992). \\
\hline \multirow[b]{2}{*}{ Perceived Risk } & $\begin{array}{l}\text { A Perceived Risk Facets } \\
\text { Perspective. Int. J. Hum. Comput. } \\
\text { Stud. 59(1): } 451-474 .\end{array}$ & $\begin{array}{l}\text { Predicting e-Services } \\
\text { Adoption }\end{array}$ & $\begin{array}{l}\text { Featherman M.S and } \\
\text { Pavlou P.A (2003). }\end{array}$ \\
\hline & $\begin{array}{l}\text { The role of trust, perceived risk, } \\
\text { and their antecedents," Decision } \\
\text { Support Systems (442), 2008, pp. } \\
544-564 .\end{array}$ & $\begin{array}{l}\text { "A trust-based } \\
\text { consumer decision- } \\
\text { making model in } \\
\text { electronic commerce }\end{array}$ & $\begin{array}{l}\text { Kim, D. J., D. L. } \\
\text { Ferrin, and Rao, R } \\
\text { (2008). }\end{array}$ \\
\hline
\end{tabular}

Table 3:- Authors for technology enablers and disablers

\section{III. THEORITICAL FRAMEWORK}

$>$ The Unified Theory of Acceptance and Use of Technology was created tobe a solution to the challenges and contradictionscreated by the eight theories that where integrating to develop the UTAUT model (Venkatesh, Morris and Davis, 2003). The aim of this theoryis tounderstand behavioural intention of usingtechnology and the subsequent actual usage attitude as the dependent variable. The UTAUT theory consistof these elements: performance expectancy, effort expectancy, social influence, and facilitating conditions.

The Unified Theory of Acceptance and Use of Technology

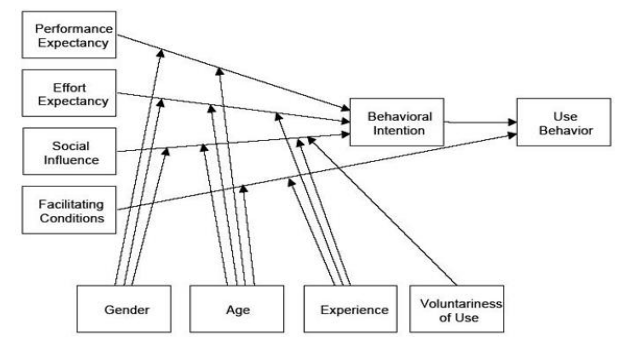

Fig 1:- Flow diagram of UTAUT process

Source:Venkatesh, Morris, Davis and Davis, 2003 
Total Task Fit (TTF) model aims topositively impact on performance and to be appliedwhen technology design matchesuser's tasks undertake.The TTF model have the following elements: characteristics of task and technology, performance impact and utilization.

- $\quad$ The Total Task Fit (TTF) model

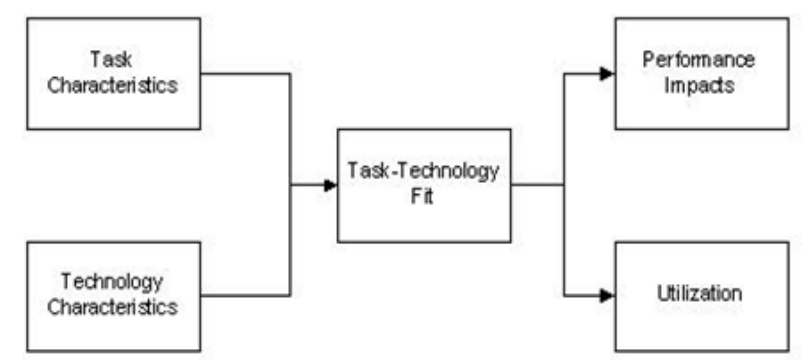

Fig 2:- Flow diagram of TTF process

Source: Goodhue and Thomson, 1995.

> The Tax Compliance Model (TCM) emphasizethat variables for demographics influence compliance of taxpayer by their effecton tax evasionattitudes, perceptions and opportunities.The TCM model have the following elements:tax compliance behaviour, demographic (e.g.- age, gender and education), tax evasionoptions (e.g. level of income, source of income and position), attitudes and perceptions (e.g. tax system fairness and peer influence) and tax system (e.g. complexity of the tax system, detection chances, penalties and tax rates)

\section{- $\quad$ Tax Compliance Model (TCM)}

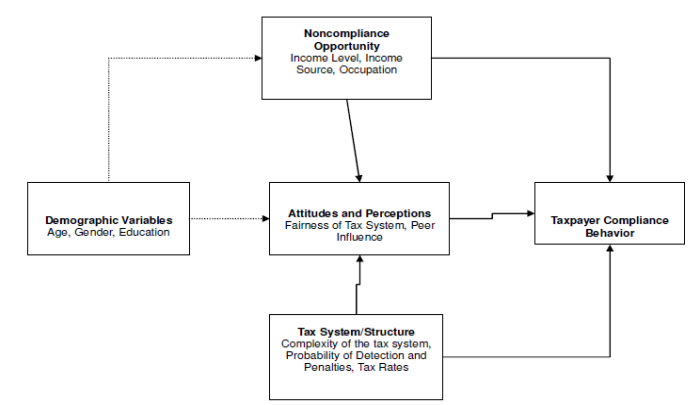

Fig 3:- Flow diagram of the Tax Compliance Model

Source:Fischer, Wartick and Mark, 1992.

Technology adoption and usage theories being UTAUT, TTF and Tax Compliance were applied independently in various settings, however, in these studies these models have been integrated toaddress the research problem. These prior theories were used independently from each other in previous studies. Integration of these theories assisted in developing solutions to address the identified problem and gaps being unique to the conditions in South Africa.

\section{CONCEPTUAL RESEARCH MODEL}

The developed conceptual model for adoption and usage of e-filing in this study givesa solid foundation for analysis work done to which is based on tested hypothesis suitable for exploration. The conceptual model was constructed with the combination of elements UTAUT, TTF and Tax Compliancemodels.Conceptual structure statements offer basic theory of what the study is about together with reasonswhy this phenomenon take place (Bickman and Rog, 2008). Conceptual model is a graphic business model giving details about the key factors, ideas or variables that needs explorationregarding the relationships between them (Miles et al., 1994).Explored hypotheses regarding the conceptual research modelhas elementssourcedout of UTAUT, TTF and Tax Compliance models. Theory can'tbe proven by multiple outcomesbecause if one instance refuting that findings it means then that the theory demonstrate it as false (Popper, 1968). Theory is established by comparing observable data and hypotheses with more than two constructs explain the relationships (Popper, 1968) The UTAUT, TTF and TCMtheories cannot be used in isolation to address the challenges of technology adoption and usage in South Africa context as they might be irrelevant, hence they were integrated in this study.

\section{$>$ Hypotheses}

Behavioural intention (BI) for adopting e-filing is the dependent variable.

\section{Hypotheses per each element:}

H1: Performance Expectancy affecting performance impact.

H2: Tax Compliance behaviour affecting behavioural intention to use the e-filing.

H3: Effort Expectancy affecting behavioural intention to use the e-filing.

H4: Performance Impact affecting behavioural intention to use the e-filing.

H5: Social Influence affectingbehavioural intention to use the e-filing.

H6: Facilitating conditions affecting intention to use the efiling.

H7: Intention to use e-filing is affected by attitude, perceived usefulness and ease of use.

H8: Tax Compliance behaviouraffectinge-filing adoption and usage.

The Conceptual Research Model for Adoption and Usage of e-filing 


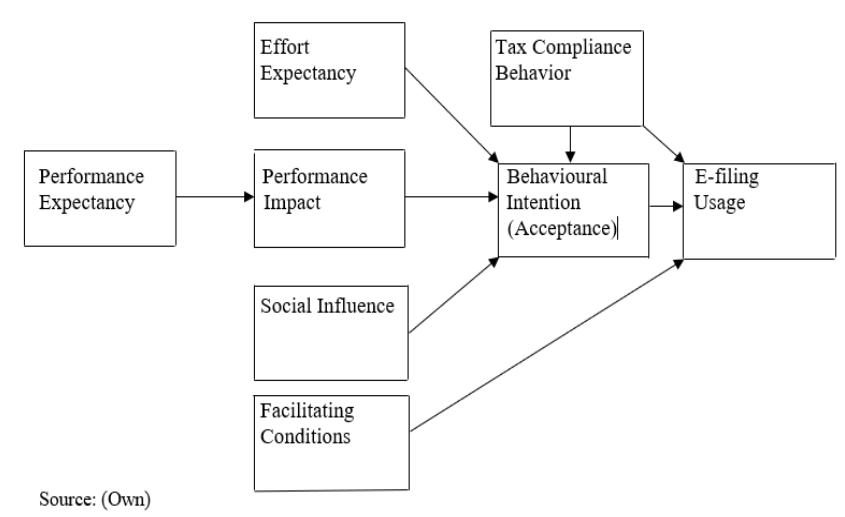

Fig 4:- The flow diagram of The Conceptual Model for adoption and usage of e-filing

\section{METHODOLOGY}

This study is based on critical reality with regard to epistemological position, it indicates that existence of reality exist beyond what is seen or observed.This study took subjectivism stance with regard toontological position, it indicated that social phenomena occur based on the ideas and subsequent actions of social participants (EasterbySmith, Thorpe and Lowe, 2006). Reality beyond what is observed in relationto the adoption and usage of the e-filing is required forunderstanding what drive taxpayers' to use or not use e-filing. This paper took a positivistic stance that implies that research outcomes are presented as objective facts and verified truths (Crotty, 1998). Research strategy in this study is a positivist using a quantitative method for data collection. Sampling technique adopted in this studywas a simple random and sample frame wasSouth African taxpayers submitting returns annually. A questionnaire was administered for collection of primary data that was analyzed using the structural equation modelling(SEM), confirmatory factor analysis (CFA), path modelling and Smart PLS software.

\begin{tabular}{|c|c|c|}
\hline $\begin{array}{l}\text { Research } \\
\text { Process }\end{array}$ & Methods & Reason \\
\hline $\begin{array}{l}\text { Res earch } \\
\text { Philosophy }\end{array}$ & Positivist & $\begin{array}{l}\text { Objective facts and } \\
\text { established truth }\end{array}$ \\
\hline $\begin{array}{l}\text { Research } \\
\text { Strategy }\end{array}$ & Quantitative & To reach many participants \\
\hline Data Collection & $\begin{array}{l}\text { Survey } \\
\text { (Questionnaire) }\end{array}$ & Easy to administer \\
\hline Sample Frame & $\begin{array}{l}\text { Taxpayers } \\
\text { (manual \& e-filers) }\end{array}$ & $\begin{array}{l}\text { Only individuals submitting } \\
\text { tax returns }\end{array}$ \\
\hline $\begin{array}{l}\text { Sample } \\
\text { Technique }\end{array}$ & $\begin{array}{l}\text { Simple Random } \\
\text { Sampling }\end{array}$ & $\begin{array}{l}\text { All participants have a } \\
\text { chance of being selected }\end{array}$ \\
\hline Unit Analysis & Individuals & $\begin{array}{l}\text { Individuals available } \\
\text { everywhere in the country }\end{array}$ \\
\hline Data Analysis & $\begin{array}{l}\text { Structural } \\
\text { Equation } \\
\text { Modelling }\end{array}$ & $\begin{array}{l}\text { Statistical technique for } \\
\text { studying relationships } \\
\text { between latent variables (or } \\
\text { constructs) }\end{array}$ \\
\hline
\end{tabular}

Table 4:- depicts the summary of Methodology

\section{DISCUSSIONS OF RESULTS}

\section{A. Structural Equation Modelling Approach}

Structural Equation Modeling (SEM) was appliedfor this paper for data analysis. SEM is a technique used for assessing relationships between elements(SchermellehEngel, Klein \& Moosbrugger, 2017). Prior authors believed in creating theoretical concepts and use two or more structural equations to validate proposed causal relationships (Bollen, 1989; Brewer et al., 2015; Byrne, 2016; Hair et al, 2016; Henseler et al., 2015 and Hair et al., 2017). SEM performing same functions as regression analysis with an additional benefit being the ability to measure relationship on elementsand account for measurement errorat the same time (Hox, et al., 2017). SEM is a well knowtechnique used for data analysis being able to address numerous modelling challenges relating to the indigeneity among elements (Preacher, Zhang \& Zyphur, 2016).

\section{B. Structural Equation Modelling, A Component based Approach}

Statistical analyses where done on the Measurement and structural models using the Smart PLS software.Discussions below are relating to the variablesdescriptive statistics and reliability of the model. The Structural Equation Modelling, Confirmatory Factor Analysis and Path Modelling assessed in this studyare discussed below. Model Fit was assessed by applyingConfirmatory Factor Analysis (CFA) as well asreliability and validity of the scales used in the questionnaire. Scales validity was established by comparingthe shared variance together with the average variance extracted (AVE). Path Modelling (PM) was achieve by testing Model fit and hypothesis. Significant statistical relationships between the elements was assessed using the bootstrap resampling method. Evidence on the reliability and validity of the assessment model is presented below in table 5 .

\section{Measurement Model Assessment}

> Summary of Measurement Model Assessment (Confirmatory Factor Analysis)

Conceptual model has eight elements, which are Behavioural Intension, Effort Expectancy, E-filing Usage, Facilitating Conditions, Performance Expectancy, Performance Impact, Social Influence and Tax Compliance Behaviour. Results of testing elements for reliability and validity are shown in table 5 below. 


\begin{tabular}{|c|c|c|c|c|c|c|c|c|}
\hline \multirow{2}{*}{\multicolumn{2}{|c|}{$\begin{array}{l}\text { Research } \\
\text { constructs }\end{array}$}} & \multicolumn{2}{|c|}{ Scale Items } & \multirow[t]{2}{*}{\begin{tabular}{|l|} 
Item-to- \\
Total \\
Correlati \\
on Value \\
\end{tabular}} & \multirow[t]{2}{*}{\begin{tabular}{|l|} 
Cronbac \\
h's \\
Alpha \\
Value
\end{tabular}} & \multirow{2}{*}{\begin{tabular}{|l|} 
Compos \\
ite \\
Reliabil \\
ity \\
Values
\end{tabular}} & \multirow[t]{2}{*}{$\begin{array}{l}\text { Average } \\
\text { Variance } \\
\text { Extracted } \\
\text { (AVE) }\end{array}$} & \multirow[t]{2}{*}{$\begin{array}{l}\text { Factor } \\
\text { Loadings }\end{array}$} \\
\hline & & Mean & SD & & & & & \\
\hline & BI1 & 2.452 & 1.071 & 0.675 & & & & 0.845 \\
\hline \multirow[t]{5}{*}{ BI } & BI2 & 2.283 & 1.066 & 0.755 & \multirow[t]{2}{*}{0.847} & \multirow[t]{2}{*}{0.908} & 0.766 & 0.895 \\
\hline & B I3 & 2.226 & 1.062 & 0.717 & & & & 0.885 \\
\hline & EE1 & 2.393 & 1.113 & 0.675 & & & & 0.808 \\
\hline & EF2 & 2.497 & 1.066 & 0.625 & & & & 0.769 \\
\hline & EE3 & 2.854 & 1.029 & 0.718 & & & & 0.795 \\
\hline \multirow[t]{4}{*}{$\mathbf{E E}$} & EE4 & 3.042 & 1.128 & 0.72 & \multirow[t]{3}{*}{0.888} & \multirow[t]{3}{*}{0.914} & 0.639 & 0.794 \\
\hline & EE5 & 2.94 & 1.1 & 0.724 & & & & 0.799 \\
\hline & EE6 & 2.863 & 1.126 & 0.758 & & & & 0.83 \\
\hline & EU1 & 2.158 & 1.067 & 0.666 & & & & 0.817 \\
\hline \multirow[t]{5}{*}{$\mathbf{E U}$} & EU2 & 2.357 & 1.062 & 0.784 & \multirow[t]{2}{*}{0.828} & \multirow[t]{2}{*}{0.897} & 0.745 & 0.922 \\
\hline & EU3 & 2.438 & 1.196 & 0.6 & & & & 0.791 \\
\hline & FC1 & 2.464 & 1.263 & 0.526 & & & & 0.732 \\
\hline & FC2 & 2.818 & 1.225 & 0.71 & & & & 0.827 \\
\hline & $\mathrm{FC3}$ & 3.185 & 1.186 & 0.625 & & & & 0.73 \\
\hline \multirow[t]{4}{*}{ FC } & FC4 & 2.777 & 1.11 & 0.593 & \multirow[t]{2}{*}{0.812} & \multirow[t]{2}{*}{0.868} & \multirow[t]{2}{*}{0.57} & 0.758 \\
\hline & FC5 & 2.735 & 1,051 & 0.552 & & & & 0.722 \\
\hline & PE1 & 2.777 & 1.147 & 0.82 & & & & 0.919 \\
\hline & PE2 & 2.845 & 1.096 & 0.807 & \multirow[b]{2}{*}{0.913} & \multirow[b]{2}{*}{0.945} & & 0.914 \\
\hline \multirow[t]{4}{*}{ PE } & PE3 & 2.839 & 1.122 & 0.846 & & & 0.851 & 0.935 \\
\hline & PII & 2.43 & 1.172 & 0.79 & \multirow{5}{*}{0.91} & & & 0.863 \\
\hline & PI2 & 2,440 & 1.196 & 0.789 & & & & 0.866 \\
\hline & PI3 & 2.863 & 1.187 & 0.713 & & & & 0.813 \\
\hline \multirow[t]{5}{*}{ PI } & PI4 & 2.682 & 1.119 & 0.778 & & 0.933 & 0.736 & 0.869 \\
\hline & PI5 & 2.518 & 1.126 & 0.789 & & & & 0.877 \\
\hline & SII & 2.503 & 1.094 & 0.661 & & & & 0.818 \\
\hline & SI2 & 2.414 & 1.051 & 0.767 & & & & 0.885 \\
\hline & SIB & 2.768 & 1.144 & 0.655 & & & & 0.76 \\
\hline SI & SI4 & 2.497 & 1.118 & 0.772 & 0.866 & 0.903 & 0.653 & 0.862 \\
\hline & SI5 & 2.744 & 1.165 & 0.581 & & & & 0.701 \\
\hline & TCB1 & 2.804 & 1.138 & 0.739 & & & & 0.825 \\
\hline & TCB2 & 2.685 & 1.135 & 0.686 & & & & 0.792 \\
\hline & TCB3 & 2.985 & 1.048 & 0.708 & & & & 0.794 \\
\hline $\begin{array}{l}\text { R } \\
\text {. }\end{array}$ & TCB4 & 2.985 & 1.045 & 0.766 & & & & 0.845 \\
\hline & TCB5 & 2.955 & 1.024 & 0.727 & 0.875 & 0.906 & 0.619 & 0.815 \\
\hline & ТСB6 & 2.589 & 1.008 & 0.457 & & & & 0.631 \\
\hline
\end{tabular}

Note: $B I=$ Behavioural Intension; $E E=$ Effort Expectancy; EU=Efiling Usage; $F C=$ Facilitating Conditions; $P E=$ Performance; Expectancy; $P I=$ Performance Impact ; SI =Social Influence; $T C B=$ Tax Compliance Behaviour; $S D=$ Standard Deviation ; $C R=$ Composite Reliability $A V E=$ Average Variance Extracted

\section{* Scores: 1 -Strongly Disagree; 3 -Moderately Agree; 5 - StronglyAgree}

Table 5:- Scale Accuracy Analysis

\section{$>$ Reliability and Validity tests in Confirmatory Factor Analysis}

Guidance in determining reliability and validity were sourced from previous studies conducted by Devine \& Hughes, 2016; Canivez, 2016; Willoughby et al., 2017). Reliability indicatesvariance amount in an item as an element rather than to the error (Chau, 1997). Discriminant and convergent validity assessed using Average Variance Extracted (Crego et al., 2015).

\begin{tabular}{|l|l|l|l|}
\hline & Alpha & Reliability & $\begin{array}{l}\text { Average } \\
\text { Variance } \\
\text { Extracted } \\
\text { (AVE) }\end{array}$ \\
\hline BI & 0.847 & 0.908 & 0.766 \\
\hline EE & 0.888 & 0.914 & 0.639 \\
\hline EU & 0.828 & 0.897 & 0.745 \\
\hline FC & 0.812 & 0.868 & 0.57 \\
\hline PE & 0.913 & 0.945 & 0.851 \\
\hline PI & 0.91 & 0.933 & 0.736 \\
\hline SI & 0.866 & 0.903 & 0.653 \\
\hline TCBS & 0.875 & 0.906 & 0.619 \\
\hline
\end{tabular}

Table 6:- Measurement Instrument Assessment (Confirmatory Factor Analysis)

\section{$>$ Testing for Reliability \\ - Cronbach's Alpha (CA)}

Measurement scale was evaluated applying Cronbach's alpha coefficient composite reliability (CR) to verify the internal consistency in checking the reliability of the measurements. Cronbach's alpha coefficient over 0.6 is a recommended reliable values (Diedenhofen and Musch (2016). Instrument reliability was measured with Cronbach alpha andall values are above the accepted threshold of 0.6 , as indicated in Table 6 and indicating that all assessment instruments are reliable.

\section{- $\quad$ Composite Reliability $(C R)$}

Composite reliability index over 0.7 is recommended (Diedenhofen and Musch (2016). Facilitating Conditions hasthesmallest composite reliability $(\mathrm{CR})$ value of 0.868 and Performance Expectancy has the highest composite reliability value of 0.945 in this study.Composite reliability exceeded the threshold of greater than 0.7 for all values in this study as indicatedin Table 6 .

\section{- Average Variance Extracted}

Variance in indicators was determined by applying the average variance extracted indicated by the latent variable. An elementwith AVE value that is greater than 0.5 is considered reliable (Wilcox, 1996). All variables fall within the acceptable threshold of 0.5 according to AVE results in Table 6.

AVE is calculated manually with this formula: $\mathrm{AVE}=\Sigma \gamma \mathrm{yi} 2 /[\Sigma \gamma \mathrm{yi} 2+\Sigma \varepsilon \mathbf{i}]$.

All scales were internally consistent and reliable as per extracted constructs reliabilities and the average variance according to results shown in table 6.

\section{- Convergent Validity}

The level that anelement converges in its indicators by explainingthe items' variance is measured by the convergent validity (Zelkowitz and Cole, 2016). Item-total 
correlation and factor loadingmeasures verifies convergent validity (Crego et al., 2015; Hair et al., 2016). Factor loadingestimates over 0.5 are shown in table 5indicatingconvergent validity. The lowest representing Tax Compliance Behaviour (TCB6) show the lowestfactor loading of 0.631 whilePerformance Expectancy (PE3) have the highest factor loading of 0.935 .

\section{- Discriminant validity}

Correlation matrix is applied to measure the discriminant validity(Chinomona, (2011). Discriminant validity was confirmed as the value for correlation between variables is recommended to be below 1.0 and intercorrection values for all variables are below 1.0 as indicated in Table 7. All measurement in this study meets the recommended threshold as per results obtained and the highest being value is 0.761 . Average variance extracted value was compared to their Highest Shared Variance (HSV) to assess the discriminant validity which was confirmed (Hox, et al., 2017).

\begin{tabular}{|c|c|c|c|c|c|c|c|c|}
\hline & BI & EE & EU & FC & PE & PI & SI & TCB \\
\hline BI & 1 & & & & & & & \\
\hline EE & 0.445 & 1 & & & & & & \\
\hline EU & 0.761 & 0.509 & 1 & & & & & \\
\hline FC & 0.538 & 0.697 & 0.569 & 1 & & & & \\
\hline PE & 0.353 & 0.707 & 0.43 & 0.571 & 1 & & & \\
\hline PI & 0.555 & 0.65 & 0.728 & 0.64 & 0.6 & 1 & & \\
\hline SI & 0.439 & 0.555 & 0.551 & 0.607 & 0.43 & 0.549 & 1 & \\
\hline TCB & 0.587 & 0.71 & 0.619 & 0.723 & 0.61 & 0.731 & 0.58 & 1 \\
\hline
\end{tabular}

Table 7:- Correlation Matrix

Discriminant validity is obtained through comparison of Average Variance Extracted (AVE) and Highest Shared Variance (HSV).Discriminant validityexist when AVE is greater than HSV. Table 8 indicates results thatshowing all AVEs being greater than the HSVs of the elements that confirmthe discriminant validity.

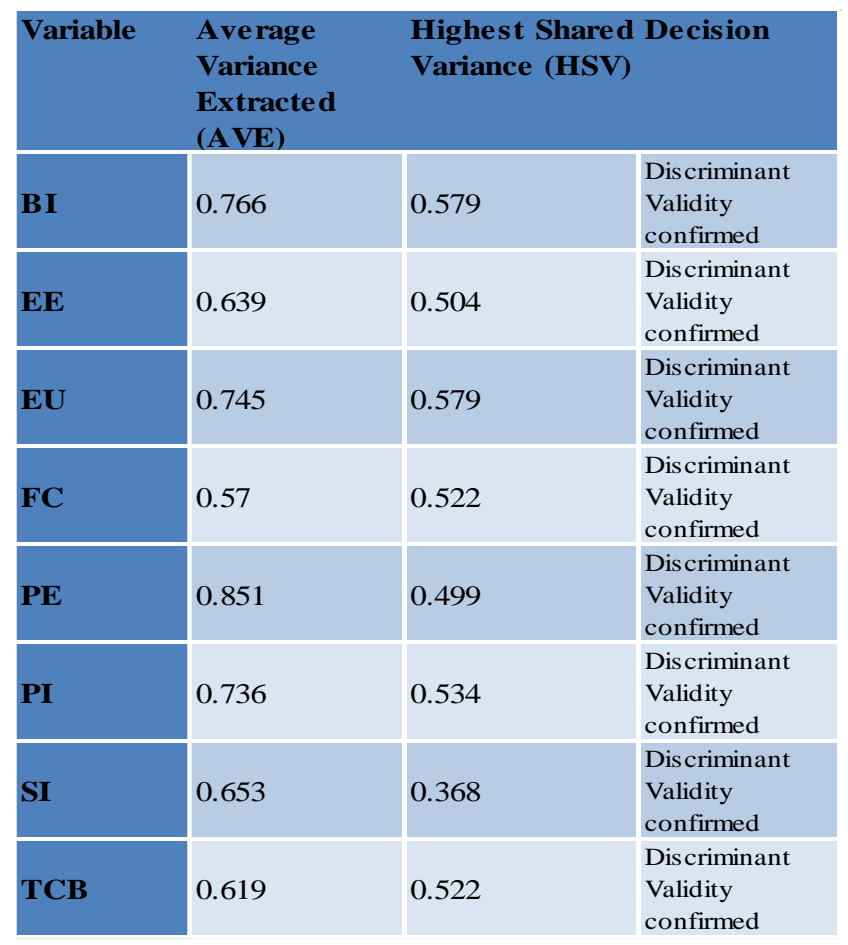

Table 8:- Comparison between AVE and HSV Results

\section{Model Fit Summary-Measurement Model}

Three categories of Model fit analysis outcome are absolute fit indices, incremental fit indices and parsimony fit indices. The CMIN or the Chi-square $(\chi 2 / \mathrm{df})$, Normed Fit Index (NFI), Goodness-Of-Fit Index(GFI), Root Mean Square Error of Approximation (RMSEA), Tucker Lewis Index (TLI), Comparative Fit index (CFI) and Incremental Fit Index (IFI) indices were extracted from the analysis result obtained. The Chi-square (CMIN/DF) threshold of 3 is acceptable, however, in table 3 it was found to be 2.124 (Chinomona (2011). Acceptable threshold level of 0.900 is recommended for the CFI, however, in this study it was found to be0.908 (Hooper, Coughlan and Mullen(2008). GFI acceptable threshold of at least 0.9 is recommended and GFI was found to be 0.914 (Baumgartner and Hombur, 1996). Relative fit index (RFI)value of 0.9 is recommended and in this study it was found to be 0.906 (McDonald and Ho, 2002). Normed fit index (NFI) threshold is acceptable at a value of 0.900 and it was found to be 0.909 (Bentler and Bonett, 1980). The incremental fit index (IFI) 0.903 was realised and it exceeds therecommended value of 0.900 (Bollen, 1989). The Tucker-Lewis Index (TLI) acceptable threshold is 0.900 and in this study it was found to be 0.915 (Hooper et al., 2008). The root mean square error of approximation (RMSEA) thresholds is acceptable at 0.08 and it was found to be 0.069 in this study. Results shows all model fit indices beingat recommendedlevels as indicated in the Table 9. 


\begin{tabular}{|c|c|c|c|}
\hline $\begin{array}{l}\text { Model Fit } \\
\text { Indices }\end{array}$ & $\begin{array}{l}\text { Acceptable } \\
\text { Threshold }\end{array}$ & $\begin{array}{l}\text { Current } \\
\text { Study } \\
\text { Threshold }\end{array}$ & $\begin{array}{l}\text { Decision: } \\
\text { Acceptable } \\
\text { /Unaccepta } \\
\text { ble }\end{array}$ \\
\hline $\begin{array}{l}\text { Chi-Square } \\
\text { Value: } \chi 2 /(d f)\end{array}$ & $<3$ & 2.124 & Acceptable \\
\hline $\begin{array}{l}\text { Comparative Fit } \\
\text { Index (CFI) }\end{array}$ & $>0.900$ & 0.908 & Acceptable \\
\hline $\begin{array}{l}\text { Goodness of Fit } \\
\text { Index (GFI) }\end{array}$ & $>0.900$ & 0.914 & Acceptable \\
\hline $\begin{array}{l}\text { Incremental Fit } \\
\text { Index (IFI) }\end{array}$ & $>0.900$ & 0.909 & Acceptable \\
\hline $\begin{array}{l}\text { Normed Fit } \\
\text { Index (NFI) }\end{array}$ & $>0.900$ & 0.903 & Acceptable \\
\hline $\begin{array}{l}\text { Tucker Le wis } \\
\text { Index (TLI) }\end{array}$ & $>0.900$ & 0.915 & Acceptable \\
\hline $\begin{array}{l}\text { Random } \\
\text { Measure of } \\
\text { Standard Error } \\
\text { Approximation } \\
\text { (RMSEA) }\end{array}$ & $<0.08$ & 0.069 & Acceptable \\
\hline
\end{tabular}

Table 9:- Model Fit Summary- Measurement Model

\section{$>\quad$ Structural Model Assessment and Hypotheses Testing}

The structural model indicates PE, TCB and PI having aneffect on the behavioural intention while $\mathrm{BI}$ and FC, BI and TCB having a positive effect on EU. Hypotheses assessing model fit were tested after Path analysis was conducted. Path analysis was assessed to establish the magnitude of hypothesised causal connections between the elements. Model fit path analysis outcomes are presented in table 10 as: $\chi^{2 / d f}=2.811 ; \mathrm{CFI}=0.903$; IFI $=$ 0.907; NFI $=0.933$; TLI $=0.906$; RMSEA $=0.078$. The results indicated all model fit indices being within the recommended levels.

\begin{tabular}{|c|c|c|c|}
\hline $\begin{array}{l}\text { Model Fit } \\
\text { Indices }\end{array}$ & $\begin{array}{l}\text { Acceptable } \\
\text { Threshold }\end{array}$ & $\begin{array}{l}\text { Current } \\
\text { Study } \\
\text { Threshold }\end{array}$ & $\begin{array}{l}\text { Decision: } \\
\text { Acceptable/ } \\
\text { Unacceptable }\end{array}$ \\
\hline $\begin{array}{l}\text { Chi-Square } \\
\text { Value: } \chi^{2 /(d f)}\end{array}$ & $<3$ & 2.811 & Acceptable \\
\hline $\begin{array}{l}\text { Comparative Fit } \\
\text { Index (CFI) }\end{array}$ & $>0.900$ & 0.903 & Acceptable \\
\hline $\begin{array}{l}\text { Incremental Fit } \\
\text { Index (IFI) }\end{array}$ & $>0.900$ & 0.907 & Acceptable \\
\hline $\begin{array}{l}\text { Normed Fit } \\
\text { Index (NFI) }\end{array}$ & $>0.900$ & 0.933 & Acceptable \\
\hline $\begin{array}{l}\text { Tucker Lewis } \\
\text { Index (TLI) }\end{array}$ & $>0.900$ & 0.906 & Acceptable \\
\hline $\begin{array}{l}\text { Random } \\
\text { Measure of } \\
\text { Standard Error } \\
\text { Approximation } \\
\text { (RMSEA) }\end{array}$ & $<0.08$ & 0.078 & Acceptable \\
\hline
\end{tabular}

Table 10:- Model Fit Summary- Measurement Model

\section{> Structural Model Assessment (Path Analysis)}

Measurement of the hypothesised structural model isdone first before examining the causal relationships between latent variables by path analysis (Henseler, Hubona and Ray, 2016). Somelatent variables directly or indirectly affect other latent variables in the model resulting in estimated outcomesthat explains the relationship of these latent variables as it is emphasised by structural equation modelling (Lefcheck, 2016; Hair et al., 2017). Table 11 presented the estimated results obtainedthroughhypothesis testing. Table 11 indicates if a hypothesis is rejected or accepted and shows the hypotheses, path coefficients and t-statistics. Significant relationship indicators are $\mathrm{t}>1.96$ while a higher path coefficients means stronger relationships between the latent variables (Chinomona, Lin, Wang and Cheng, 2010).

\begin{tabular}{|c|c|c|c|c|c|}
\hline $\begin{array}{l}\text { Hypothesized } \\
\text { Relationship }\end{array}$ & Hypothesis & $\begin{array}{l}\text { Path Co- } \\
\text { efficient }\end{array}$ & T-Statistics & P-Value & Outcome \\
\hline $\mathrm{PE} \rightarrow \mathrm{PI}$ & $\mathrm{H} 1$ & 0.597 & 13.606 & 0.000 & $\begin{array}{l}\text { Significant \& } \\
\text { supported }\end{array}$ \\
\hline $\mathrm{TCB} \rightarrow \mathrm{BI}$ & $\mathrm{H} 2$ & 0.37 & 4.603 & 0.000 & $\begin{array}{l}\text { Significant \& } \\
\text { supported }\end{array}$ \\
\hline $\mathrm{EE} \rightarrow \mathrm{BI}$ & H3 & -0.041 & 0.569 & 0.569 & $\begin{array}{l}\text { Rejected and } \\
\text { insignificant }\end{array}$ \\
\hline $\mathrm{PI} \rightarrow \mathrm{BI}$ & $\mathrm{H} 4$ & 0.251 & 3.722 & 0.000 & $\begin{array}{l}\text { Significant \& } \\
\text { supported }\end{array}$ \\
\hline $\mathrm{SI} \rightarrow \mathrm{BI}$ & H5 & 0.109 & 1.789 & 0.074 & $\begin{array}{l}\text { Supported } \\
\text { but } \\
\text { insignificant }\end{array}$ \\
\hline $\mathrm{FC} \rightarrow \mathrm{EU}$ & H6 & 0.115 & 1.775 & 0.076 & $\begin{array}{l}\text { Supported } \\
\text { but } \\
\text { insignificant }\end{array}$ \\
\hline $\mathrm{BI} \rightarrow \mathrm{EU}$ & $\mathrm{H} 7$ & 0.586 & 11.084 & 0.000 & $\begin{array}{l}\text { Significant \& } \\
\text { supported }\end{array}$ \\
\hline $\mathrm{TCB} \rightarrow \mathrm{EU}$ & $\mathrm{H} 8$ & 0.191 & 3.623 & 0.000 & $\begin{array}{l}\text { Significant \& } \\
\text { supported }\end{array}$ \\
\hline
\end{tabular}

Note: $B I=$ Behavioural Intension; $E E=$ Effort Expectancy; $E U=$ e-filing Usage; $F C=$ Facilitating Conditions; $P E=$ Performance Expectancy; $P I=$ Performance Impact; SI = Social Influence; $T C B=$ Tax Compliance Behaviour

Table 11:- Path Analysis Results

Table 11 showsthe outcomesof eight hypotheses that were assessed in this study. Seven hypotheses were positive with an exception of 33 being rejected. After testing $\mathrm{H} 5$ and H6, insignificant results were obtainedas the p-value is over $0.05(0.074,0.075)$ while $\mathrm{H} 3$ was negative and it was rejected. 


\section{Structural Equation Modelling (SEM)}

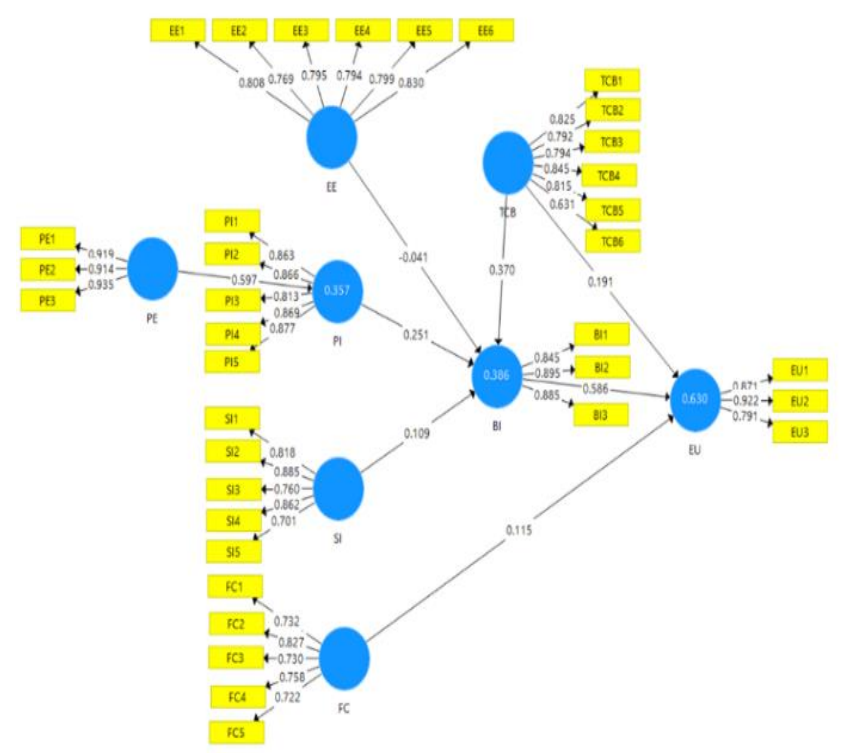

Fig 5:- Flow diagram of Structural Equation Modelling

Path coefficients presented in figure 5shows the significant levels being measured with the p-values and tstatisticsfrom the eight hypotheses tested. Hypotheses significance are recommended at a $95 \%$ or higher level of significance $(\geq 95 \%)$ and p-value at $\leq 0.05$ (Hastie et al., 2009); Hair et al., 2010). The t-statistics with a threshold of greater than 1.96 are acceptable for the relationship purpose. Hypotheses and path coefficients arepresented firstfollowed by the t-statistics and p-valuesshowing the significant levels of the relationships and lastly the column showing the decision of accepting or rejectingthe proposed hypotheses.A strong relationship between the dependent and the independent variables is indicated by the path coefficients (Hsu, 2008). Three hypotheses were found to have significant level at $\mathrm{p}<0.05$ after testing the probability value which is also known as $\mathrm{p}-$ value.

Five out of the eight hypotheses were statistically significant with the exclusion three being $\mathrm{H} 5$ and H6 that were positive butnot significant while $\mathrm{H} 3$ was negative and insignificant. Performance Expectancy (PE) and Performance Impact (PI) had strongest relationship as per $\beta=0.597 ; t=13.606 ; p=0.000$ andsecond strong relationship was between Behavioural Intension (BI) and Efiling Usage (EU) with $\beta=0.586 ; \mathrm{t}=11.084 ; \mathrm{p}=0.000$. Relationship amongst Tax Compliance Behaviour (TCB) and Behavioural Intension (BI) is thethird strongest with $\beta=0.370 ; t=4.603 ; p=0.000$ and in the fourth placeis Tax Compliance Behaviour (TCB) and E-filing Usage (EU) having $=\beta 0.191 ; \mathrm{t}=3.623 ; \mathrm{p}=0.000$. Weakest relationship in this studyat the third place is amongst Facilitating Conditions (FC)and E-filing Usage (EU) with $=\beta 0.115 ; \mathrm{t}=$ 1.775; $\mathrm{p}=0.076$ and the second weakest relationship is amongst Social Influence (SI) and Behavioural Intension (BI) with $=\beta 0.109 ; \mathrm{t}=1.789 ; \mathrm{p}=0.074$. The weakest relationship of all hypotheses was amongst Effort Expectancy (EE) and Behavioural Intension (BI) having $=\beta$ $-0.041 ; \mathrm{t}=0.569 ; \mathrm{p}=0.569$.

\section{$>$ Summary of the results for this study}

Results after testing hypotheses as per data analysed indicates path coefficients of $\mathrm{H} 1, \mathrm{H} 2, \mathrm{H} 3, \mathrm{H} 4, \mathrm{H} 5, \mathrm{H} 6, \mathrm{H} 7$ and $\mathrm{H} 8$ to be $0.597,0.370,-0.041,0.251,0.109,0.115$, $0.586,0.191$ respectively. Results from this study shows seven latent variables havingpositive relationships except H3 beingrejectedafter tested negative. Performance expectancy and performance impact had the strongest relationship with path coefficient value of 0.597 while relationship amongsteffort expectancy and behavioural intension beingthe weakest with a path coefficient of 0.041 . Testing confirming reliability and validity of the measurement was done. Relationships between the constructs as per hypotheses in this study were assessed using Smart PLS software for SEM.

\section{STUDY RESULTS AND INTERPRETATIONS}

Results and interpretations for this study are presented below.Hypothesis one resultsconfirmed positive and significant relationship among performance expectancy and performance impactbeing $\mathrm{t}=13.606, \mathrm{p}=0.000$ and $\mathrm{a}$ path coefficient of 0.597 .This results are similar tofindings by Venkatesh et al. (2003) indicating thatperformance expectancy affects performance impact. The results mean that performance impact was achieved when expectations relating to the performance are met. Test results of hypothesis two showsa positive and significant relationship amongtax compliance behaviour and behavioural intension, thus $\mathrm{t}=4.603, \mathrm{p}=0.000$ with a path coefficient of 0.370 . These outcomes aresimilar to findings by Marziana, Norkhazimah and Mohmad (2010), for discovering taxpayers' attitude and perception regarding tax system fairness being a vitalfactor significantlyinfluencing tax compliance behaviour. Integrity, credibility and trustworthiness of government affect taxpayers' decision to adopt e-filing. Results after testing hypothesis three showseffort expectancy and behavioural intension having a negative relationship being $\mathrm{t}=0.569, \mathrm{p}=0.569$ with a path coefficient of -0.041 and its therefore rejected. These results contradict with findings from previous studies that discovered effort expectancy correlatingwith behavioural intention (Agarwal and Prasad, 1999; Thompson et al., 1991; Venkatesh et al., 2003). Findings from these studies were however, not done in the context of e-filing for filing returns. These outcomes are indicating effort expectancy having a negative impact behavioural intension, thus taxpayers need an easy to use system. Results from testing hypothesis fourshows a path coefficient of 0.251 together with a positive and significant relationship amongperformance impact and behavioural intension at $\mathrm{t}=3.722, \mathrm{p}=0.000$. These outcomes confirm findings by Goodhue and Thompson (1995) who stated that performance impact affectsbehavioural intension of using e-filing. Continuous use of e-filingby taxpayers may occur as there is no alternative system except the manual submission. E-filing needs to be continuously upgraded to enable tax authority toadd more functionalities in simplifying tax returns submissions. Results from testing hypothesisfive confirmed a positive and insignificant relationship amongst social influence and behavioural 
intension of $\mathrm{t}=1.789, \mathrm{p}=0.074$ with a path coefficient of 0.109 . Results from this study confirm claimsthat taxpayers are use online application that are preferred by their peers, friends and family members(Venkatesh and Davis, 2000). Social influence plays an important role for influencing users to accept information system, so e-filingdesigners must develop strategies to ensure that usersget a value forwhen using the electronic filing.Results after testing hypothesis six shows a path coefficient of 0.115 meaningthat facilitating conditions has a positive effect on e-filing insignificantlyas per $(t=1.775, p=0.074)$. These outcomes confirm findings from prior study discovering that focusing on facilitating conditions only does not automatically predict e-filingusage as factors affecting information system usage are plenty (Fu et al., 2006). Efiling is used at any time of a day and tax authority must ensure the availability of support personnel to attend to system challenges from users. Results for testing hypothesis seven shows a positive and a significant relationship amongst behavioural intension and e-filing usage as per $\mathrm{t}=11.084, \mathrm{p}=0.000$ with a path coefficient of 0.586. These outcomes confirm findings from previous studies stating that even if all factors affecting actual use of information system are in place, decision to use technology is not guaranteed. (Agarwal and Prasad, 1999). Hypothesis eight testing indicatesa strong positive and significant relationship amongsttax compliance behaviour and e-filing usage as per $\mathrm{t}=3.623, \mathrm{p}=0.000$ with a path coefficient of 0.191. This study results concur with claim from previous study showing a tax compliant behaviour and e-filing usage having a positive relationship (Fischer et al.,1992). Theseoutcomesmean that ethical taxpayers submitting tax returns correctly and on time are likely to use e-filing platforms than less ethical taxpayers.Tax compliance behaviour changes over time, continuous monitoring by authority is needed.

\section{A MODEL FOR ADOPTION AND USAGE OF E-FILING}

Figure 5 below shows a model for adopting and using the e-filing after the conceptual model was amended according to constructs testing which were done.

\section{The Model for Adoption and Usage of E-filing}

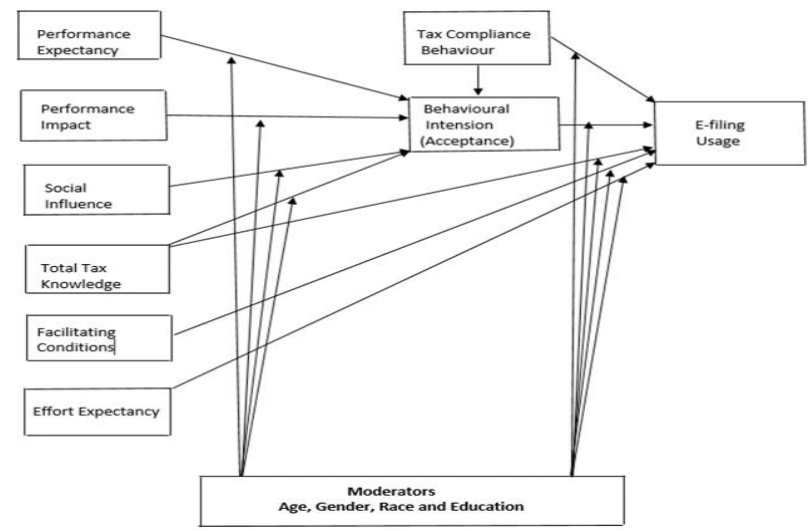

Fig 6:- A Model for Adoption and Usage of E-filing
This model for adoptingand using e-filing being developed in this paperhas the following constructs as tested results: Effort expectancy, performance expectancy, facilitating conditions, social influence, performance impact, tax compliance behaviour and total tax knowledge. Most of these elements were validated in this study except total tax knowledge that is anadditional element for this model. It can be conclusion that these elements are the determinants for the adopting and usingthe e-filing. Additional construct being total knowledge was used when reviewing the conceptual model, higher education is linked to a higher possibility of tax compliance in previousliterature. Taxpayers with tertiary education comply tax obligations than their counterparts without tertiary education.

\section{CONCLUSION}

Model fit summary presented in table 10shows all model fit indices being, chi-square value, comparative fit index, incremental fit index, normed fit index, tucker Lewis index and random measure of standard error approximation, havingvalues greater thanthe recommended levels. Path analysis outcomes show five hypotheses being supported significantly excludingH5 and $\mathrm{H} 6$ that are positive but not significant, H3 was rejected after tested negative and insignificant. Reliability and validity tests in confirmatory factor analysis (CFA) respectively indicates outcomes verifying reliability and validity of measurement. This study confirmed factors for adopting and using efiling to be effort expectancy, performance expectancy, facilitating conditions, social influence, performance impact and tax compliance behaviour.Tax authorities can consider to practically apply the model developed in this study to achieve an optimal usage of the e-filing.Research problemwas that despite South Africa having excellent efiling, queues at its branch offices are still observable being for taxpayers submitting manual tax returns.This study shared more inside information for exploring reasonswhy othertaxpayers adopt and use the e-filing while others do not.This study has come up with a solution to the research problem by developing a model for adopting and using the e-filing.Reasons relating to why taxpayers are using the efiling while others are not are now known as perresults from this study. Tax authority need to focus on these factors to influence taxpayers to optimally use the e-filing.

\section{REFERENCES}

[1]. Agarwal, R. and Prasad, I (1999). "Are individual differences germane to the acceptance of new information technologies?" Decision Sciences, Vol. 30, No. 2, pp. $361-391$

[2]. Ajzen, I. (1991). The theory of planned behaviour. Organisational behaviour and human decision processes, 50(1), pp. 179-211.

[3]. Alm, J., Cherry, T., Jones, M. and McKee, M (2012). Social Programs as positive inducements for tax participation. Journal of Economic Behaviour \& Organization 84(1): 85-96. 
[4]. Azmi, A. A. C., and Kamarulzaman, Y. (2010). Adoption of Tax e-filing: A ConceptualPaper. African Journal of Business Management Vol., 4(5), 599-603.

[5]. Barjoyai, B. (1992). Tax illiteracy in Malaysia: Problems and solutions. ACCAMADIA, Journal of Faculty of Accountancy, Faculty of Accountancy, UiTM Shah Alam 11(2): 6-35.

[6]. Barodiva, P and Bhargava, A (2015). E-Filing Awareness of Income Tax returns - International Journal of Multidisciplinary Research and Development. Volume: 2, Issue: 6, 119-122 June 2015.

[7]. Baumgartner, H., and Homburg, C. (1996). Applications of structural equation modeling in marketing and consumer research: A review. International Journal of Research in Marketing, 13(2), 139-161.

[8]. Bentler, P.M. and Bonnet, D.C. (1980). Significance Tests and Goodness of Fit in the Analysis of Covariance Structures, Psychological Bulletin, 88 (3), 588-606.

[9]. Beynon-Davies, P. (2005). Constructing electronic government: the case of the UK inland revenue. International Journal of Information Management 25(1): 3-20

[10]. Bickman, L. and Rog, G.J (2008). The SAGE handbook of applied social research methods, Sage publications.

[11]. Bollen, K. A. (1989). Structural equations with latent variables. New York, NY: Wiley

[12]. Brewer, C.S., Chao, Y.Y., Colder, C.R., Kovner, C.T. and Chacko, T.P. (2015). A structural equation model of turnover for a longitudinal survey among early career registered nurses. International journal of nursing studies, 52(11), pp.1735-1745.

[13]. Byrne, B.M. (2016). Structural equation modelling with AMOS: Basic concepts, applications, and programming. Routledge.

[14]. Canivez, G.L. (2016). Bifactor modelling in construct validation of multifactored tests: Implications for understanding multidimensional constructs and test interpretation. Gottingen, Germany: Hogrefe Publishers.

[15]. Carter, L and Belanger, F (2005). "The Utilization of E-Government Services: Citizen Trust, Innovation and Acceptance Factors", Information Systems Journal, vol. 15, n. 1: 5-25. http://dx.doi.org/10.1111/j.13652575.2005.00183.x

[16]. Carter, L., Schaupp, L.C., Hobbs, J. and Campbell, R. (2011a). The role of security and trust in the adoption of online tax filing. Transforming Government: People, Process, Policy, 5(4), pp. 303-318.

[17]. Carter, L., Schaupp, L.C. and McBride, M.E. (2011b). The U.S. e-file initiative: an investigation of the antecedents to adoption from the individual taxpayers' perspective. E - Service Journal, 7(3), pp. 219.
[18]. Chau, P.Y., 1997. Re-examining a model for evaluating information centre success using a structural equation modelling approach. Decision Sciences, 28(2), pp.309-334.

[19]. Chau, Y. K and $\mathrm{Hu}$, J. H (2001). Information technology acceptance by individual professionals: a model comparison approach. Decision Sciences, 32.

[20]. Chinomona, R. (2011). Non-mediated channel powers and relationship quality: A case of SMEs in Zimbabwe channels of distribution.National Central University, Taiwan, 1-175.

[21]. Chinomona, R., Lin, J.Y.C., Wang, M.C.H. and Cheng, J.M.S. (2010). Soft power and desirable relationship outcomes: the case of Zimbabwean distribution channels. Journal of African Business, 11(2), pp.182-200.

[22]. Crego, C., Samuel, D. B., and Widiger, T. A. (2015). The FFOCI and other measures and models of OCPD.

[23]. Crego, C., Gore, W.L., Rojas, S.L. and Widiger, T.A. (2015). The discriminant and convergent validity of the Personality Inventory for DSM-5. Personality Disorders: Theory, Research, and Treatment, 6(4), p.321.

[24]. Crotty, M (1998). The Foundation of Social Research: Meaning and Perspectives in the Research Process. London: Sage.

[25]. Cronbach, L. J (1951). "Coefficient alpha and the Internal structure of test", Psychometrical, Vol. 16, No. 3, pp. $297-334$.

[26]. Crotty, M (1998). The Foundation of Social Research: Meaning and Perspectives in the Research Process. London: Sage.

[27]. Davis, F.D (1989). Perceived Usefulness, Perceived Ease-of-Use, and User Acceptance of Information Technology, MIS Quarterly, 13(3), pp. 319-339.

[28]. De Castro, J. A. C., Cordero, M. J. D., De Chavez, J. R., Gabia, M. F. P., Mortel, S. A. A., Yortas, J.C.,Manongsong, J. L. and Pateña, A. D. (2015). Awareness on BIR e-Filing and Payment System: Basis for Efficient Revenue Transactions. Asia Pacific Journal of Academic Research in Business Administration, 1(1), 32-40.

[29]. DeLone, W. H. and McLean, E. R. (2003). The DeLone and McLean model of information systems success: A ten-year update. Journal of Management Information Systems, 19,4,9-30.

[30]. Devine, R.T. and Hughes, C. (2016). Measuring theory of mind across middle childhood: reliability and validity of the silent films and strange stories tasks. Journal of Experimental Child Psychology, 149, pp.23-40.

[31]. Diedenhofen, B. and Musch, J. (2016). A Web Interface and $\mathrm{R}$ Package for the Statistical Comparison of Cronbach's Alpha Coefficients. International Journal of Internet Science, 11(1).

[32]. Dillon, A and Morris, M (1996). User acceptance of information technology: theories and models. In: M. Williams (ed.), Annual Review of Information 
Science and Technology, Vol. 31, (Medford, NJ: Information Today).

[33]. Easterby-Smith, M., Thorpe, R and Lowe, A (2006). Management Research: Anintroduction, 2nd Edition, Sage Publications

[34]. Featherman, M. S. and P. A. Pavlou (2003). "Predicting e-services adoption: a perceived risk facets perspective," International Journal of Human-Computer Studies (594), 2003, pp. 451474.

[35]. Fischer CM, Wartick M, Mark M (1992). Detection Probability and Taxpayer Compliance: A Review of the Literature. J. Acc. Lit. 11: 1-46.

[36]. Fishbein M, Ajzen I (1975). Belief, Attitude, Intention and Behaviour: An introduction to theory and research, Reading, MA: Addison Wesley.

[37]. Fu, J. R., Farn, C. K and Chao, W. P (2006). Acceptance of electronic tax filing: A study of taxpayer intentions. Information \& Management 43, 109-126

[38]. Gilbert, D., Balestrini, P and Littleboy, D. (2004). Barriers and Benefits in the Adoption of eGovernment. The International Journal of Public Sector Management, 17(4), 286-301.

[39]. Goodhue, D.L and Thompson, R. L (1995) Tasktechnology fit and individual performance $M I S$ Quarterly; Jun 1995; 19, 2; ABI/INFORM Global pg. 213-236.

[40]. Gupta, B., Dasgupta, S., and Gupta, A. (2008). Adoption of ICT in a government organization in a developing country: An empirical study. Journal of Strategic Information Systems, 17(2), 140-154.

[41]. Hair Jr, J.F., Hult, G.T.M., Ringle, C. and Sarstedt, M. (2016). A primer on partial least squares structural equation modelling (PLS-SEM). Sage Publications.

[42]. Hair, J.F., Hult, G.T.M., Ringle, C.M., Sarstedt, M. and Thiele, K.O. (2017). Mirror, mirror on the wall: A comparative evaluation of composite-based structural equation modelling methods. Journal of the Academy of Marketing Science, 45(5), pp.616632.

[43]. Hastie, T., Tibshirani, R., and Friedman, J. (2009). The elementsof statistical learning: Data mining, inference, and prediction(2nd ed.). New York, NY: Springer.

[44]. Hsu SH. (2008). Developing an index for online customer satisfaction: adaptation of American Customer Satisfaction Index. Expert Syst Appl. 2008;34(4):3033-3042.

doi: 10.1016/j.eswa.2007.06.036.

[45]. Hair, J. F., Black, W. C., Babin, B. J., and Anderson, R. E. (2010). Multivariate data analysis (7th ed.). Englewood Cliffs: Prentice Hall

[46]. Hasseldine, J., Holland, K. and Rijt, P.V. (2009). The Management of Tax Knowledge. The Association of Chartered Certified Accountants, ACCA, London.

[47]. Henseler, J., Hubona, G. and Ray, P.A. (2016). Using PLS path modelling in new technology research: updated guidelines. Industrial management \& data systems, 116(1), pp.2-20.

[48]. Henseler, J., Ringle, C.M. and Sarstedt, M. (2015). A new criterion for assessing discriminant validity in variance-based structural equation modelling. Journal of the academy of marketing science, 43(1), pp.115-135.

[49]. Hooper, D., Coughlan, J., and Mullen, M. R. (2008). Structural Equation Modelling: Guidelines for Determining Model Fit. Electronic Journal of Business Research Methods, 6(1), 53-60.

[50]. Hox, J.J., Moerbeek, M. and Van de Schoot, R. (2017). Multilevel analysis: Techniques and applications. Routledge.

[51]. Kim, D. J., D. L. Ferrin and RAO, R (2008). "A trust-based consumer decision-making model in electronic commerce: The role of trust, perceived risk, and their antecedents," Decision Support Systems (442), 2008, pp. 544-564.

[52]. Kirchler, E., Niemirowski, A., and Wearing, A. (2006). Shared subjective views, intent to cooperate and tax compliance: Similarities between Australian taxpayers and tax officers. Journal of Economic Psychology, 27, 502-517.

[53]. Kumar, M., and Anees, M (2014). E-filing: Creating new revolution in taxation of India. Global Journal of Finance and Management, 6(4), 379384. Retrieved from www.ripublication.com

[54]. Lai, M and Choong, K. (2010). Motivators, Barriers and Concerns in Adoption of Electronic Filing System: Survey Evidence from Malaysian Professional Accountants. American Journal of Applied Sciences, 3(4), 10-15.

[55]. Lee, J., Kim, H.J and Ahn, M. J (2011). "The Willingness of E-Government Service Adoption by Business Users: The Role of Offline Service Quality and Trust in Technology", Government Information Quarterly, vol. 28: 222-230.

[56]. Lefcheck, J.S. (2016). Piecewise SEM: Piecewise structural equation modelling in $r$ for ecology, evolution, and systematics. Methods in Ecology and Evolution, 7(5), pp.573-579.

[57]. Leitner, C. (2003). E-Government in Europe: The state of affairs, Proceedings of the e-Government 2003 Conference, Como, Italy.

[58]. Marziana Hj. Mohamad, Norkhazimah Ahmad, Mohmad Sakarnor Deris (2010). Perceptions of Taxpayers With Level of Compliance: A Comparison in the East Coast Region, Malaysia: Journal of Global Business and Economics, vol.1, issue 1, pages 241-257

[59]. McDonald, R.,P and Ho, M. R (2002). Principles and Practice in Reporting Structural Equation Analyses.UniversityofIllinoisatUrbana-Champaign Psychological Methods by the American Psychological Association, Inc.

Vol. 7, No. 1, 64-82

[60]. Miles, M.B., Huberman, A.M., Huberman, M.A., and Huberman, M. (1994). Qualitative data analysis: An expanded sourcebook. Sage. 
[61]. Moorthy, M. K., Samsuri, A. S. B., Hussin, S. B. M., Othman, M. S. B., and Chelliah, M. K. (2014). E-Filing Behaviour among Academics in Perak State in Malaysia. Technology and Investment, 5(2), 79-94.

[62]. Mustapha, B. (2015). Evaluation of e-Tax Quality Implementation Criteria: the Case ofSelf-Employed Taxpayers in Nigeria. International Journal of Computer andElectronics Research, 4(2), 39-45.

[63]. Popper, Karl. (1968). The Logic of Scientific Discovery. New York : Harper.

[64]. Preacher, K.J., Zhang, Z. and Zyphur, M.J. (2016). Multilevel structural equation models for assessing moderation within and across levels of analysis. Psychological methods, 21(2), p.189.

[65]. Rehman, M., Esichaikul, V., and Kamal, M. (2012). Factors Influencing e-GovernmentAdoption in Pakistan. Transforming Government: People, Process and Policy, 6(3),258-282.

[66]. Santhanamery, T., and Ramayah, T. (2015). Understanding the Effect of Demographic andPersonality Traits on the e-filing Continuance Usage Intention in Malaysia. Global Business Review, 16(1), 1-20.

[67]. Schermelleh-Engel, K., Klein, A. and Moosbrugger, H. (2017). Estimating nonlinear effects using a latent moderated structural equations approach. In Interaction and nonlinear effects in structural equation modelling (pp. 203-238). Routledge.

[68]. Schlemenson, A (1992). Organisational structure and human resources in tax administration. In $\mathrm{R}$. M. Bird \& M. C. d Jantscher (Eds.), Improving tax administration in developing countries (pp. 343364). Washington, DC: International Monetary Fund.

[69]. Silvani, C.A (1992). Improving Tax Compliance. In Richard M. Bird and Milka Casanegra de Jantscher (Eds), Improving Tax Administration In Developing Countries. Washington D.C. International Monetary Fund, Publication Service.

[70]. Thompson, R., Higgins, C and Howell, J (1991). Personal computing: toward a conceptual model of utilization. MIS Quarterly, 15(1), 124-143.

[71]. United Nations (2005). Global e-Government readiness report 2005: From e-government to einclusion.

[72]. Van der Berg, S and Bhorat, H (1999). The present as a legacy of the past: The labour market, inequality and poverty in South Africa. (DPRU Working Paper 01/29) Development Policy Research Unit, University of Cape Town, South Africa.

[73]. Venkatesh, V and Davis, F.D (2000). A Theoretical Extension of the Technology Acceptance Model for longitudinal field studies. International Journal of Management Sciences, 46(2), pp 186-204.

[74]. Venkatesh, V., Morris, M., Davis, G. and Davis, F. (2003). "User acceptance of information technology: toward a unified view", MIS Quarterly, Vol. 27 No. 3, pp. 425-478.
[75]. Wang, Y.S. (2002). The adoption of electronic tax filing systems: an empirical study. Government Information Quarterly, 20(1), pp. 333-352.

[76]. Wasao, D. (2014). The effect of online tax system on tax compliance among small taxpayersin east of Nairobi tax district. MSc. in Finance thesis, University of Nairobi, Kenya.

[77]. Willoughby, M.T., Kuhn, L.J., Blair, C.B., Samek, A. and List, J.A. (2017). The test-retest reliability of the latent construct of executive function depends on whether tasks are represented as formative or reflective indicators. Child Neuropsychology, 23(7), pp.822-837.

[78]. Wilcox, R. R. (1996). Statistics for the social sciences. Academic Press.

[79]. Wirtz, B. W., and Piehler, R. (2016). EGovernment Applications and public personnel Acceptance: An Empirical Analysis of the Public Servant Perspective. International Journal of Public Administration, 39(3), 238-247.

[80]. Zelkowitz, R.L. and Cole, D.A. (2016). Measures of emotion reactivity and emotion regulation: Convergent and discriminant validity. Personality and Individual Differences, 102, pp.123-132. 